\title{
MANAJEMEN PEMBELAJARAN BERBASIS GREEN SCHOOL MENINGKATKAN RELIGIUSITAS SANTRI PONDOK NUN TANJUNG KARANG KUDUS
}

\author{
Intan Siska Santoso \\ IAIN Kudus, Indonesia \\ intansiska1605@gmail.com \\ Fifi Nofiaturrahmah \\ IAIN Kudus, Indonesia \\ fifinofiaturrahmah@gmail.com
}

\begin{abstract}
Abstrak
Artikel ini mendiskusikan tentang 1) Manajemen pembelajaran PAI berbasis green school. 2) hasil manajemen pembelajaran PAI berbasis green school. 3) faktor pendukung dan faktor penghambat manajemen pembelajaran PAI berbasis green school. Jenis penelitian ini adalah penelitian lapangan dengan pendekatan kualitatif. Subjek dalam penelitian ini adalah santriwati dan guru PAI di Pondok Pesantren Nun Tanjung Karang Kudus. Pengumpulan data menggunakan metode observasi, wawancara dan dokumentasi. Metode analisis data yang digunakan yaitu reduksi data, penyajian data, penarikan kesimpulan dan verifikasi. Hasil analisis data dapat diperoleh temuan-temuan penelitian sebagai berikut: 1) manajemen pembelajaran PAI berbasis green school dilakukan di luar ruangan antara lain menyesuaikan dengan tema yang dibahas, dan menyatu dengan alam. 2) hasil manajemen pembelajaran PAI berbasis green school berupa pemahaman santri terkait tema pembelajaran yang diberikan, yang ditunjukkan dengan meningkatnya religiusitas. 3) faktor pendukung dan faktor penghambat manajemen pembelajaran PAI berbasis green school; lingkungan, kurikulum 2013 dan kurikulum khusus, serta tenaga pendidik dari pondok pesantren Gontor dan pondok pesantren Arrisalah yang memiliki pengetahuan dan kualitas mengajar yang baik.
\end{abstract}

Kata Kunci :Manajemen Pembelajaran PAI, Green School, Religiusitas

\begin{abstract}
Abstrack
This paper discussed; 1) the PAI learning based on green schools. 2) the results of green school-based PAI learning 3) the supporting factors of green school-based PAI learning. This is a field research with a qualitative approach. The subjects in this study are the students and the PAI teachers at Pondok Nun Tanjung Karang Kudus. The data collection used are the method of observation, interviews and documentation. Data analysis methods used are data reduction, data presentation, drawing conclusions and verification. The results of the data analysis can be obtained as research findings as follows: 1)PAI learning based on green school is conducted outdoors in the area of Pondok Nun, adjusted to the theme which is discussed, and merged with nature. 2) the learning outcomes of green school-based PAI are in the form of students' understanding of the learning themes provided, which are indicated by increased spiritual value. 3) the supporting factors of green school-based PAI learning are the environment, 2013 curriculum and exclussive curriculum, as well as educators from Gontor and Arrisalah boarding school having good teaching knowledge and quality.
\end{abstract}

Keywords: PAI Learning Management, Green School, Spiritual 


\section{A. Pendahuluan}

Sejak tahun 1930-an filsafat pendidikan perenialisme telah ada dilatar belakangi sebagai bentuk reaksi terhadap kalangan progresifisme. Sebagaimana kita ketahui bahwa filsafat progresifisme membuat pendidikan menjadi semakin jauh dari visi hidup yang sebenarnya. (Gandhi 2014, 163) Tujuan pendidikan perenialisme yaitu membantu peserta didik mempersiapkan dan menginternalisasikan nilai-nilai kebenaran yang abadi dengan tujuan untuk mencapai kebijakan dan kebaikan dalam hidup. Universal dan abadi merupakan sifat dari nilai-nilai kebenaran filsafat perenialisme. (Gandhi 2014, 173) Kebenaran sejati dalam hal ini misalnya nilai moral pada pendidikan akidah akhlak yang disampaikan guru dalam pembelajaran dan pembiasaan dalam kehidupan sehari-hari akan tertanam pada diri siswa. Jika siswa memiliki moral yang baik dalam kehidupan sehari-hari, ia akan dihargai oleh orang lain. Produk nyata dari filsafat perenialisme yaitu munculnya pembelajaran berbasis green school yaitu adanya kenyataan kembali pada budaya tradisionalisme. Seperti yang kita ketahui, Indonesia merupakan negara dengan mayoritas penduduknya beragama Islam. Sehingga mayoritas penduduknya membutuhkan pendidikan berlandaskan Islam.

Terdapat tiga pembagian dalam pendidikan, yaitu: pendidikan informal, pendidikan formal, dan pendidikan non formal. Pondok pesantren merupakan salah satu bentuk pendidikan informal. Pada pelaksanaan pembelajarannya merupakan bentuk nyata dari filsafat tradisionalisme, yaitu terciptanya pondok pesantren konvensional yang tidak mempunyai kelas, tidak membedakan usia, dan sistem bandongan. Namun seiring berjalannya waktu pondok pesantren dikemas menjadi pendidikan formal dengan jalan didirikannya tempat pendidikan yang disebut madrasah dengan status masih satu yayasan dengan pondok pesantren.

Terbentuknya pondok pesantren bukan tanpa adanya landasan hukum, namun tentunya pendirian ini mempunyai payung hukum yang kuat, yaitu UU No. 18 Tahun 2009. Pada undang-undang tersebut mengharuskan bahwa pondok pesantren disamakan dengan pendidikan formal lainnya, yang membedakan hanya pada muatannya. Sehingga diharapkan output dari pondok pesantren tidak tertinggal jauh dari anak yang menempuh pendidikan formal lainnya. Sistem Pendidikan Nasional 
yaitu keseluruhan komponen pendidikan yang saling terkait secara terpadu untuk mencapai tujuan pendidikan nasional.

Pendidikan menurut undang-undang pada Sistem Pendidikan Nasional yaitu : sebuah sistem yang terstruktur dan terdiri dari komponen-komponen yang saing berkaitan satu dengan yang lain untuk mencapai suatu tujuan yang diharapkan. Tujuan pendidikan dapat terwujud secara efektif dan efisien apabila optimalisasi pendidikan dilakukan, yaitu dengan cara mengoptimalkan dari setiap komponenkomponen pendidikan.

Berikut ini merupakan beberapa komponen yang termasuk dalam pendidikan nasional yaitu lingkungan, sarana-prasarana, sumberdaya, dan masyarakat. (Munirah 2015, 234) Maka diperlukan sebuah manajemen dengan seorang manajer yang dapat mengelola pendidikan sehingga tujuan pendidikan itu dapat tercapai. Pelaksanaan pendidikan pada dasarnya tak bisa terlepas dari pelaksanaan pembelajaran. Hal ini karena pokok utama sebuah pendidikan adalah pembelajaran.

Suatu pembelajaran dapat dikatakan berhasil tidak hanya manakala semua kompetensi dalam materi pembelajaran dapat terlampaui sesuai dengan waktu yang ditentukan, namun peserta didik dapat menerima pemahaman atas pembelajaran yang disampaikan. Mayoritas guru beranggapan bahwa tugas guru yang utama yaitu menyampaikan seluruh materi pembelajaran sesuai dengan kurun waktu yang ditentukan. Mereka mengesampingkan pemahaman yang diperoleh peserta didik. Maka dari itu diperlukanlah manajemen pembelajaran yang bertujuan agar peserta didik dapat menerima pemahaman yang disampaikan guru.

Manajemen pembelajaran berasal dari dua kata, yang "To Manage" merupakan kata kerja yang mempunyai arti, yaitu: mengelola, menyelenggarakan, mengatur, menjalankan, melaksanakan, mengendalikan, menangani, memimpin. dari bahasa latin, yaitu mano yang berarti tangan, menjadi manus berarti bekerja berkali-kali dengan menggunakan tangan, diberikan tambahan agree kemudian menjadi managiare yang berarti melakukan sesuatu berkali-kali dengan menggunakan tangan. Menurut bahasa prancis "manage" mempunyai arti aksi melakukan bimbingan atau kepemimpinan. Sedangkan pembelajaran dari kata belajar yang diberikan tambahan kata depan "pem" dan kata belakang "an". Secara istilah pembelajaran yaitu proses belajar yang dilakukan oleh guru kepada peserta didik 
yaitu berupa transfer knowledge dan transfer kepribadian atau nilai karakter melalui penyampaian materi yang diajarkan. (Kompri 2014)

Manajemen pembalajaran merupakan upaya pelaksanaan pembelajaran, dengan tujuan pencapaian hasil dari kegiatan belajar mengajar sesuai dengan tujuan dan hemat berdasarkan finansial maupun alokasi waktu. Pada pelaksanaan pengelolaan pembelajaran guru berperan sebagai manajer mempunyai wewenang dan tanggung jawab untuk melakukan langkah-langkah manajemen meliputi perencanaan pembelajaran, pengorganisasian, pembelajaran, pengendalian atau pengarahan, serta evaluasi pembelajaran. (Hilwiah 2019)

Penulis setelah melakukan survey pada lokasi penelitian yaitu di pondok Nun, mendapatkan informasi dari wawancara, hasil pengamatan maupun dokumentasi mengenai data santri di pondok Nun dari latar belakang keluarga yang berbeda, antara lain dari golongan fakir, miskin, yatim, piatu, dan sabilillah, dan terlantar. Sebagian dari mereka merupakan pindahan dari pondok, sekolah dasar negeri maupun swasta. Pondok Nun menawarkan pembelajaran berbasis alam yang menyenangkan, salah satunya pada mata pelajaran agama. Tulisan ini bertujuan mendeskripsikan tentang pembelajaran agama berbasis alam dalam pengembangan religiusitas.

Berdasarkan ketertarikan peneliti tersebut maka muncul berbagai pertanyaan; Bagaimana manajemen pembelajaran PAI berbasis green school di Pondok Pesantren Nun Tanjung Karang Kudus? Bagaimana hasil manajemen pembelajaran PAI berbasis green school di Pondok Pesantren Nun Tanjung Karang Kudus? Bagaimana faktor pendukung dan faktor penghambat manajemen pembelajaran PAI berbasis green school di Pondok Pesantren Nun Tanjung Karang Kudus? Adanya pengembangan ilmu itulah tulisan ini diarahkan.

Penelitian ini bertujuan mengetahui manajemen pembelajaran PAI berbasis green school di Pondok Pesantren Nun Tanjung Karang Kudus, mengetahui hasil manajemen pembelajaran PAI berbasis green school di Pondok Pesantren Nun Tanjung Karang Kudus, dan mengetahui faktor pendukung dan faktor penghambat manajemen pembelajaran PAI berbasis green school di Pondok Pesantren Nun Tanjung Karang Kudus. 
Adapun manfaat teoritis adalah bagi pembaca Mendeskripsikan tentang "Manajemen Pembelajaran Berbasis Green school meningkatkan religiusitas santri di Pondok Pesantren Nun Tanjung Karang Kudus" merupakan bekal ilmu baru untuk menambah pengetahuan dan bagi Peneliti lainnya Penelitian ini menjadi sumbangan pengetahuan secara teori bagi peneliti selanjutnya agar dapat dikembangkan lebih lanjut lagi. Adapun secara praktis Bagi lembaga pendidikan, agar dijadikan bahan pertimbangan bagi lembaga pendidikan pada umumnya dan pondok pesantren pada khususnya dalam rangka memberikan inovasi bagi pembelajaran PAI melalui pembelajaran berbasis green school sehingga anak tidak harus belajar dikelas dan dapat menyatu dengan alam, dan dengan seperti itu diharapkan nilai religius santri pondok Nun akan meningkat.

\section{Kajian Teori}

\section{Filsafat Perenialisme}

Sejak tahun 1930-an filsafat pendidikan perenialisme mulai muncul dilatar belakangi sebagai bentuk reaksi terhadap kalangan progresifisme yang semakin membuat pendidikan menjadi semakin jauh dari visi hidup yang sebenarnya (Gandhi 2014, 163). Filsafat pendidikan perenialisme diambil dari bahasa latin, kata "philosophia perennis" yang berarti filsafat yang abadi. Abadi dalam hal ini berkaitan dengan adanya nilai-nilai dan norma (Rachman 2010, 160). Berdasarkan hal itu, filsafat pendidikan perenialisme memandang perkembangan kebudayaan sepanjang zaman merupakan sebuah pengulangan dari apa yang telah ada sebelumnya sehingga perenialisme sering disebut dengan istilah "tradisionalisme" (Gandhi 2014, 163).

\section{Manajemen Pembelajaran Berbasis Greenschool}

Manajemen pembelajaran berasal dari dua kata, yang pertama manajemen dan pembelajaran. "To Manage" merupakan kata kerja yang mempunyai banyak arti, yaitu: mengelola, menyelenggarakan, mengatur, menjalankan, mengemudikan, mengurus, melaksanakan, mengendalikan, menangani, memimpin. Selain itu, kata management berasal dari bahasa latin, yaitu mano yang berarti tangan, menjadi manus berarti bekerja berkali-kali dengan menggunakan tangan, diberikan tambahan agree kemudian menjadi managiare yang berarti melakukan sesuatu berkali-kali dengan menggunakan tangan. 
Menurut bahasa prancis kata manage mempunyai arti aksi melakukan bimbingan atau kepemimpinan. Sedangkan pembelajaran dari kata belajar yang diberikan tambahan kata depan "pem" dan kata belakang "an". Secara istilah pembelajaran yaitu proses belajar yang dilakukan oleh guru kepada peserta didik yaitu berupa transfer knowledge dan transfer kepribadian atau nilai karakter melalui penyampaian materi yang diajarkan (Kompri 2014).

Pendidikan Agama Islam (PAI) merupakan pendidikan yang mengandung materi ajar yang terdiri dari Akidah Akhlak, Alqur'an Hadis, Fikih, dan Sejarah Kebudayaan Islam. Pengertian tersebut tidak lepas dari adanya unsur yang menciptakan yaitu Allah dan Nabi Muhammad sebagai pembawa agama Islam sehingga berimplikasi adanya Alqur'an dan Assunah, selanjutnya adanya aspek muamalah dalam kehidupan sehari-hari sehingga berimplikasi adanya Fikih, aspek etika pergaulan sehingga berimplikasi pada pembelajaran akhlak, dan aspek sejarah Islam sehingga berimplikasi pada pembelajaran Sejarah Kebudayaan Islam (SKI) (Nata 2014, 134).

Green school mempunyai arti sekolah hijau atau pembelajaran berbasis alam. Maka dalam hal ini melibatkan alam sebagat tempat maupun sarana pembelajaran, atau bisa dikatakan alam merupakan laboratorium hidup. Pembelajaran berbasis green school memiliki komitmen dan secara sistematis mengembangkan program-program untuk menginternalisasikan nilai-nilai lingkungan ke dalam seluruh aktifitas sekolah. Pembelajaran berbasis green school tidak hanya mengajarkan masalah yang terjadi namun menjadikan siswa lebih berani terutama dalam hal melakukan eksplorasi lingkungan yang ada di luar kelas. Pembelajaran seperti ini akan memaksimalkan potensi anak-anak, sehingga mereka bisa berpikir secara kreatif bagaimana menciptakan lingkungan yang optimal (Purnama 2010, 84).

Setelah memahami mengenai berbagai pengertian diatas, maka dapat disimpulkan bahwa optimalisasi manajemen pembelajaran PAI berbasis greenschool yaitu suatu cara pengelolaan pembelajaran PAI dengan melibatkan fungsi dari manajemen antara lain; perencanaan, organizing, actuating, controlling, dan evaluasi dan melibatkan faktor eksplorasi lingkungan alam 
sehingga dapat menghasilkan secara lebih luas atau besar pula hasil yang di dapatkan.

Manajemen pembelajaran sebagai fungsi merupakan acuan untuk melaksanakan kegiatan agar dapat mencapai tujuan. Pada penerapannya, fungsi manajemen pembelajaran tidak memiliki perbedaan yang mencolok dengan fungsi manajemen pada umumnya, namun hanya terdapat perbedaan pada praktek pelaksanaannya. Fungsi-fungsi manajemen tersebut diantaranya (Danarwati 2018, 4):

1) Perencanaan

Perencanaan memiliki arti pemilihan dan penetapan suatu kegiatan mulai dari nama kegiatan, sarana-prasarana yang harus disiapkan, waktu dilakukan, langkah-langkah melakukan, dan oleh siapa harus dilakukan. Pada perencanaan harus dilakukan perbaikan jika dibutuhkan. Hal ini agar perencanaan mampu menyesuaikan diri dengan kebutuhan, situasi, dan kondisi (Danarwati 2018,5).

Fungsi perencanaan pada pelaksanaan pembelajaran yaitu adanya proses pengambilan keputusan oleh guru berdasarkan hasil pemikiran rasional, sasaran dan tujuan pembelajaran dan secara konkrit dibuatlah perangkai pembelajaran seperti RPP, media, bahan ajar, dan lain-lain

2) Organizing

Pada pelaksanaan organizing, pendidik mengumpulkan dan menjadikan satu antar sumber daya pada pelaksanaan pembelajaran seperti penddik, peserta didik, ilmu pengetahuan, dan media belajar seperti buku pedoman pembelajaran guru maupun buku belajar siswa.

\section{3) Actuating}

Actuating dapat pula disebut dengan pengarahan. Pengarahan yang dimaksud dalam hal ini yaitu hubungan antar manusia yang kedudukannya lebih tinggi dengan bawahannya agar bersedia mengerti dan menyumbangkan tenaganya secara efektif dan efisien dalam pencapaian tujuan suatu organisasi (Danarwati 2018). Maka actuating atau pengarahan pada hal ini dilakukan untuk guru kepada peserta didik, atau dapat diartikan sebagai pelaksanaan kegiatan belajar mengajar yang telah direncanakan guru pada tahap sebelumnya. 


\section{4) Controlling}

Controlling dapat artikan dengan pengawasan. Pengawasan merupakan salah satu proses yang dapat digunakan untuk menjamin tercapainya tujuan dari suatu perencanaan dalam lingkup organisasi. Controling dapat juga diartikan sebagai suatu cara yang digunakan secara sistematik untuk menetapkan standar pelaksanaan dengan tujuan perencanaan (Danarwati 2018).

Pada pelaksanaan controlling, guru mengamati dan mencatat setiap progres perkembangan pengetahuan dan pemahaman peserta didik atas apa yang telah disampaikan guru, selanjutnya guru melakukan tindakan untuk melanjutkan maupun mengulangi pembahasan, bahkan menentukan KKM (Kriteria Ketuntasan Minimal) disesuaikan dengan kemampuan minimal siswa.

5) Evaluating

Setiap guru harus mengetahui dan memiliki ketrampilan melakukan evaluasi. Evaluasi dalam hal ini yaitu evaluasi hasil belajar maupun evaluasi pembelajaran. Guru dianggap telah memiliki keterampilan evaluasi manakala telah mengetahui bagaimana evaluasi pembelajaran dilakukan, sebab dan tujuan diakukannya evaluasi pembelajaran (Nasution 2015, 139).

Pada pelaksanaan pembelajaran evaluasi yang biasanya digunakan untuk guru yaitu pada perubahan media, metode, maupun model pembelajaran disesuaikan dengan penyampaian teori, maupun gaya belajar peserta didik. Selain itu, sumber dokumentasi juga dapat berupa RPP, dan hasil perkembangan sikap peserta didik.

\section{Religiusitas}

Religiusitas terdiri dari kata "religi" atau "relegere" berarti mengikat (Zaenab 2017, 103). Religiusitas mempunyai arti aspek yang ada dalam lubuk hati manusia, getaran hati, maupun sikap personal yang mempunyai sifat misteri bagi orang lain, karena menafaskan intimidasi jiwa. Religiusitas memperlihatkan nafas intensitas jiwa, berupa cita rasa yang merupakan kesatuan rasio dan rasa yang ada pada manusia atau ada dalam pribadi manusia. Religiusitas merupakan nilai yang mendasari dan menuntun tindakan hidup ketuhanan manusia, dengan cara dan tujuan yang benar (Satinem 2019, 137). 
Sub nilai religius antara lain yaitu: Iman (teguh pendirian pada kepercayaan), percaya diri, cinta damai, toleransi beragama (menghargai perbedaan agama dan kepercayaan), kerja sama antar pemeluk agama dan kepercayaan, persahabatan, mencintai lingkungan, ketulusan, melindungi yang kecil dan tersisih, tidak memaksakan kehendak, dan anti buli dan kekerasan (Suheri 2010, 12),

Peningkatan religiusitas dapat dilihat dari tercapainya indikator religiusitas tersebut antara lain (Ismail 2009, 92);

a. Dimensi keyakinan atau ideological involvement,

b. Dimensi peribadatan atau ritual involvement

c. Dimensi penghayatan atau experiencal involvement

d. Dimensi Pengamalan atau consequental involvement

\section{Metode Penelitian}

Berdasarkan permasalahan diatas, jenis penelitian ini adalah penelitian lapangan (field research) dengan pendekatan kualitatif. Lokasi penelitian di Pondok Pesantren Nun Tanjung Karang Kudus. Subjek dalam penelitian ini adalah guru PAI di Pondok Pesantren Nun Tanjung Karang Kudus, santrisantriwati di Pondok Pesantren Nun Tanjung Karang Kudus. Pengumpulan data menggunakan metode observasi, wawancara dan dokumentasi. Metode analisis data yang digunakan yaitu reduksi data, penyajian data, penarikan kesimpulan dan verifikasi.

\section{B. Pembahasan Hasil Temuan}

\section{Pembelajaran PAI berbasis Green School}

Tujuan pendidikan secara umum adalah mewujudkan perubahan positif yang diharapkan pada peserta didik setelah menjalani proses pendidikan, baik perubahan pada tingkah laku individu dan kehidupan pribadinya maupun pada kehidupan masyarakat dan alam sekitarnya (Roqib 2019, 25-27). Pada penelitan ini, peneliti hanya berfokus pada hasil kedisiplinan dan religiusitas santri sebagai hasil dari manajemen pembelajaran rumpun PAI dalam hal ini Aqidah akhlak, tarikhul islamiyah, dan fiqih yaitu sebagai berikut:

Pada pembelajaran aqidah akhlak bertemakan tentang ta'awun (tolongmenolong) siswa tidak hanya diajarkan teori, melainkan langsung pada praktik di lapangan. Dampak dari pembelajaran ini, siswa tidak hanya peduli pada 
orang lain selama pelaksanaan pembelajaran, namun siswa peduli pada orangorang disekitar ketika memerlukan bantuan. Kepedulian itu juga tercermin di pondok. santri untuk saling mengingatkan kegiatan pondok terutama kegiatan yang mencerminkan religiusitas seperti sholat berjamaah, kebersihan lingkungan sebagai wujud keimanan, dan kegiatan setor hafalan maupun muroja'ah (Santoso 2020).

Menurut pernyataan Mira, dirinya diberikan tanggung jawab penuh mengingatkan agenda pondok adiknya, terutama agenda yang besifat ibadah. Meskipun pada awalnya ia mengaku menolak karena benci dengan adiknya, namun seiring dengan berjalannya waktu ia bisa menerima keberadaan adiknya dan menyayangi adiknya serta menjalankan tanggung jawabnya (Mira 2020).

Pernyataan Mira dibenarkan dengan pernyataan dari ustadzah Ani Yusmita, mengenai penyebab Mira benci pada adiknya adalah perceraian kedua orang tuanya yang menyebabkan dirinya diasuh oleh ayahnya dengan kekerasan sementara adiknya diasuh dengan mamanya dengan penuh kehangatan. Mira merasa ibunya pilih kasih dan ia tidak menerima keberadaannya harus berada pada pondok yang sama dengan adiknya, namun seiring berjalannya waktu disertai pembelajaran agama, Mira dapat menerima adiknya. Tentunya semua tidak terjadi secara instant, butuh pendekatan secara bertahap (Yusmita 2020).

Pada pondok Nun jadwal sholat lima waktu pasti dilakukan dengan berjamaah, dan bagi yang tidak mengikuti akan mendapat konsekuensi. Berdasarkan hasil observasi pada saat pembelajaran Aqidah Akhlak kelompoknya Aizza terlambat pulang ke pondok, dan saat itu pasa asatidzah Nun mencari keberadaan mereka yang ternyata masih di warung Lentog Tanjung depan selep, dan dari seberang jalan memberikan mereka pengarahan untuk segera kembali ke pondok (Santoso 2020). Berdasarkan penuturan dari Aizza, mengenai alasan mereka terlambat pulang karena dipaksa penjual lentog untuk makan diwarungnya sebagai bentuk ucapan terimakasih. Bahkan mereka dibawakan beberapa bungkus lentog dan gorengan untuk di bawa pulang ke pondok (Naja 2020). Meskipun begitu, keterlambatan mereka tetap 
tercatat sebagai ketidak disipinan, namun mereka tidak mendapatkan ta'zir karena kejujuran mereka. Kejadian seperti itu merupakan hal yang biasa, namun memang disadari mengganggu dalam manajemen waktu pembelajaran. Akibatnya mereka tidak mengikuti evaluasi pembelajaran, doa akhir pembelajaran, dan tidak mengikuti shalat dzuhur berjamaah (Santoso 2020).

Berdasarkan pernyataan dari ustadzah Aulia religiusitas santri Nun telah mengaami perkembangan yang pesat jika dibandingkan dengan semester sebelumnya Santri telah memahami pentingnya bersyukur kepada Allah dengan cara mengikut sertakan Allah dalam segala kegiatan positif dengan cara niat dan berdoa (Rahma 2020).

Berdasarkan dokumentasi kedisiplinan santri dalam mengikuti agenda pondok, mulai dari bangun tidur, sholat tahajud, antri mandi, jadwal kebersihan, jadwal setoran, jadwal makan, jadwal sholat dluha, jadwal sholat dzuhur berjama'ah, jadwal tidur siang, jadwal sholat ashar berjama'ah, jadwal muroja'ah, jadwal sholat magrib dan isya' berjama'ah, jadwal belajar kelas malam, jadwal tidur malam, hampir keseluruhan santri mengikuti. Namun, memang terdapat beberapa santri yang terlewat mengikuti jadwal sholat tahajud dan itu merupakan santri usia 6-7 tahun, dibawah 6 tahun memang dibebaskan dari jadwal tersebut, sedangkan diatas 7 tahun sudah mulai mengikuti semua kegiatan pondok tanpa terkecuali (Santoso 2020).

Berdasarkan pengakuan santri yang bernama Aizza dirinya merupakan salah satu santri yang paling susah di bangunkan untuk sholat tahajud, Meskipun begitu setiap dirinya bangun tengah malam, dirinya bergegas mengambil wudlu dan melaksanakan shalat tahajud (Naja 2020). Pernyataan Aizza diperkuat dengan pernyataan dari ustadzah Tri Ariyanti, bahwa Aizza merupakan santri dari golongan sabilillah. Putri dari ustadz Udin, yang pernah menjadi ustadz di pondok Nun, Aizza berada disini karena sebelumnya telah kecanduan televisi dan gadget bahkan hingga mengganggu waktu istirahatnya dan waktunya untuk belajar ke sekolah. Sehingga orang tuanya memutuskan untuk membawa Aizza ke pondok Nun. Tentunya proses menetralkan Aizza dari kecanduan televisi dan gadget tidaklah instan, perlu pembiasaan bertahap 
hingga Aizza bisa terlepas dari kecanduannya pada gadget dan televisi (Ariyanti 2020).

Peningkatan religiusitas terlihat dari diri Mira, yaitu pada keyakinan bahwa Allah maha mengetahui, sehingga ia mengajari adeknya yang bernama Putri untuk tidak memakai mukena yang kena najis ngompol, karena itu bagian dari najis mutawasitoh, kepeduliannya tidak hanya itu saja, namun mencuci mukena adeknya sesuai dengan cara menghilangkan najis mutawasitoh hingga tidak ada warna, bau, maupun rasa. Berdasarkan wawancara yang peneliti lakukan dengan mira, mengenai hal itu, bahwa dirinya peduli akan kesucian baju maupun badan adiknya agar ketika adiknya beribadah sholat tidak menghalangi sahnya (Santoso 2020).

\section{Faktor pendukung dan faktor penghambat manajemen pembelajaran} PAI berbasis green school di Pondok Pesantren Nun

Berdasarkan hasil observasi pada pelaksanaan pembelajaran PAI berbasis greenschool, mengenai lokasi pembelajaran yang digunakan sangat mendukung bagi pembelajaran alam. Terdapat masjid, sawah, pasar, jalan raya, pemukiman penduduk, dan lain sebagainya yang dapat digunanakan sebagai tempat belajar yang menyatu dengan alam dan lingkungan sekitar. Hal ini sesuai dengan pernyataan Hana mengenai pembelajaran di pondok Nun tidak dalam satu ruangan melainkan di alam bebas, ia pernah diajak naik angkutan umum, naik bis, ke pasar, ke taman, belajar di masjid, dan menolong orang-orang yang membutuhkan (Santoso 2020).

Media yang digunakan dalam pelaksanaan pembelajaran meliputi media yang ada di alam, sehingga selain menyatu dengan alam juga menjaga alam agar bersih dan asri (Santoso 2020). Hal ini sesuai dengan wawancara yang dilakukan kepada ustadzah Aulia mengenai media pembelajaran yang digunakan yaitu boneka jari yang terbuat dari koran. Selain sebagai pemanfaatan bahan bekas yang ramah lingkungan, media ini juga cocok dengan imajinasi anak usia SD (Rahma 2020).

Pada pelaksanaan pembelajaran rumpun PAI berbasis greenschool terdapat faktor penghambat, yaitu sebagai berikut: 
Menurut pernyataan dari Ustadzah Ani Yusmita, mengenai faktor penghambat optimalisasi manajemen pembelajaran rumpun PAI berbasis green school ini yaitu mengenai manajemen waktu pelaksanaan pembelajaran yang cenderung memakan banyak waktu berdampak pada kedisiplinan dimulainya pembelajaran setelahnya (Yusmita 2020).

Hal ini dibenarkan oleh ustadzah Tri Ariyanti mengenai durasi waktu pembelajaran PAI berbasis greenschool ini kondisional karena yang terpenting adalah tersampaikannya tujuan pembelajaran. Namun perlu adanya komunikasi antara pengampu pembelajaran PAI dengan pengampu mata pelajaran setelahnya agar tidak terjadi misskomunikasi (Ariyanti 2020).

Berdasarkan hasil pengamatan pada pembelajaran tarikhul Islamiyah, siswa sembari mendengarkan juga mencatat. Hal ini sesuai dengan pernyataan dari ustadzah Aulia mengenai bahan ajar hanya terdapat satu buku, sementara santri mencatat penjelasan yang penting-penting saja seperti nama tokoh, tahun, dan ringkasan kisah (Rahma 2020).

Perbedaan penelitian ini dengan penelitian terdahulu yang relevan yaitu sebagai berikut:

Pertama, Hasanuddin, tesis dengan judul "Implementasi Manajemen Pembelajaran Pendidikan Agama Islam di SMP Negeri 3 Percut Sei Tuan, Prodi PAI, Konsentrasi Manajemen Pendidikan Islam, IAIN Sumatera Utara, tahun 2014. manajemen pembelajaran PAI menggunakan metode penelitian kualitatif, dan mendorong peserta didik aktif dalam pelaksanaan pembelajaran dan bertujuan memberikan tugas dengan tujuan peserta didik dapat menemukan jawaban atas permasalahan yang yang diutarakan guru merupakan persamaan dalam penelitian ini dengan yang sedang diteliti oleh peneliti. Perbedaannya yaitu, pada penelitian ini objek penelitiannya anak usia SMP sedangkan yang diteliti oleh peneliti yaitu anak usia SD. Selain itu pada penelitian ini membebaskan peserta didik mencari tahu permasalahan yang dilontarkan oleh guru dengan menggunakan teknologi, sedangkan pada fpermasalahan yang diberikan guru di alam (Hasanuddin 2014).

Kedua, Teuku Mahmud, tesis, dengan judul "Manajemen Pembelajaran PAI dalam membentuk karakter siwa." Persamaannya dengan penelitian yang 
sedang diteliti oleh peneliti yaitu sama-sama meneliti tentang manajemen pembelajaran, sama-sama menggunakan metodologi penelitian kualitatif. Namun perbedaannya pada penelitian ini pembelajaran PAI dilakukan dikelas, masih kekurangansarana prasarana atau media pembelajaran, dan pembelajaran PAI sebatas transfer konwledge belum bisa sampai transfer nilai karakter, sehingga tidak ada perubahan karakter yang ada diri peserta didik. Sedangkan pada penelitian yang sedang diteliti leh peneliti pelakanaan pembelajaran berada diluar kelas, menyatu dengan alam, sarana prasarana serta media telah tersedia di alam, dan pelaksanaan pembelajaran PAI tidak hanya sebatas transfer konwledge namun juga transfer nilai karakter, sehingga ada perubahan karakter yang ada diri peserta didik, khususnya nilai reigius (Mahmuddin 2015).

Ketiga, Penelitian disertasi oleh Amin Murtadlo dengan judul "Manajemen Program Pembelajaran PAI (Studi Komparasi Manajemen Pogram Pembelajaran PAI antar SMA Muhammadiyah Plus Salatiga), tahun 2015. Persamaan penelitian ini dengan penelitian yang sedang diteliti oleh peneliti yaitu sma-sama meneliti tentang manajemen pembelajaran PAI, samasama berfokus pada penyampaian materi dan penanaman nilai religius peserta didik. Perbedaaannya. Sedangkan perbedaannya yitu pada penelitian ini peserta didik pada tingkatan SMA edangkan pada penelitian yang sedang diteliti oleh peneliti peserta didik pada tingkatan SD. Selain itu penelitian ini menggunakan metode penelitian studi multy kasus sedangkan penelitian yang sedang diteliti oleh peneliti menggunakan metode penelitian kualitatif deskriptif. Selain itu pada penelitian yang diteliti oleh peneliti berfokus pada manajemen pembelajaran berbasis greenschool dan dan sasarannya yaitu nilai karakter religius dan kedisiplinan (Murtadlo 2015).

Keempat, jurnal internasional karya Zarrintaj Aminrad yang berjudul 'Relationship Between Awareness, Knowledge and Attitudes Towards Environmental Education Among Secondary School Students in Malaysia"mempunyai hasil yaitu sebagai berikut:

"The importance of environmental education (EE) is well known globally among societies. The study recommended that environmental 
education subject necessarily might be considered as an independent syllabus in Malaysian education system."

Berdasarkan penjelasan diatas, bahwa Pentingnya pendidikan lingkungan (Environmental Education) dikenal secara global di kalangan masyarakat. Studi ini merekomendasikan bahwa subjek pendidikan lingkungan mungkin dapat dianggap sebagai silabus independen dalam sistem pendidikan Malaysia. Hal ini sesuai dengan penelitian yang sedang dilakukan peneliti mengenai manajemen pembelajaran di lingkungan. Perbedaannya, terletak pada mata pelajaran yang dibawakan, kalau di Malaysia seluruh mata pelajaran dilaksanakan di alam terbuka, namun di pondok Pesantren Nun Tanjung Karang, Kudus, Jawa Tengah manajemen pembelajaran berbasis alam hanya pada mata pelajaran Pendidikan Agama Islam (Aminrad 2013, 1326-1333).

\section{Simpulan}

Manajemen Pembelajaran PAI Berbasis Green School Meningkatkan Religiusitas Santri di Pondok Pesantren Nun Tanjung Karang Kudus memperoleh kesimpulan sebagai berikut: Manajemen Pembelajaran rumpun PAI (pembelajaran Aqidah khlak, Tarikhul Islamiyah, dan Fiqih) berbasis green school di Pondok Pesantren Nun meliputi perencanaan (adanya SDM pendidik alumni pondok pesantren, adanya jurnal pembelajaran, dan adanya lokasi pondok yang strategis), organizing (Pengumpulan antara pendidik, peserta didik, bahan ajar, dan media pembelajaran, namun belum tersedianya buku pegangan santri), actuating (pendidikmemberikan arahan pada santri), controlling (ustadzah yang mengampu mata pelajaran rumpun PAI telah menjalankan tugasnya dengan baik, dibuktikan dengan adanya perubahan santri dalam segi pemahaman, dan praktik pengamalan yang dipelajari dalam kehidupan sehari-hari) dan evaluating(membutuhkan alokasi waktu yang lebih, dan tidak tersedianya buku pedoman siswa)

Hasil manajemen pembelajaran PAI berbasis green school di Pondok Pesantren Nun Tanjung Karang Kudus berupa kepedulian santri, kejujuran sebagai bentuk iman kepada Allah, Sudah ada peningkatan pelaksanaan jadwal kegiatan pondok, peningkatan religiusitas santri dengan menggunakan waktu luang dengan sebaik-baiknya untuk beribadah dan ta'awun. 
Faktor pendukung manajemen pembelajaran PAI berbasis green school di Pondok Pesantren Nun Tanjung Karang Kudus yaitu lokasi pembelajaran yang dekat dengan alam, dan lingkungan masyarakat seperti; sawah, rumah warga, jalan raya, pasar, masjid, dan lain sebagainya. Selain itu media yang digunakan juga dari alam (ramah lingkungan). Sedangkan faktor penghambat yaitu; memerlukan durasi waktu yang lebih banyak sehingga berpengaruh pada waktu mengakhiri pembelajaran, adanya wewenang berupa kelonggaran waktu pembelajaran sehingga durasi waktu pembelajaran bisa berubah sewaktuwaktu, dan kurangnya komunikasi antar ustadzah pengampu, membuat adanya waktu pembelajaran yang berbenturan. 


\section{Daftar Pustaka}

Amin Murtadlo, Disertasi, "Manajemen Program Pembelajaran PAI (Studi Komparasi Manajemen Pogram Pembelajaran PAI antar SMA Muhammadiyah Plus Salatiga), tahun 2015.

Aminrad, Zarrintaj, Relationship Between Awareness, Knowledge and Attitudes Towards Environmental Education Among Secondary School Students in Malaysia, World Applied Sciences Journal. 2013, vol 22, no.9, 1326-1333

Danarwati, Yanti Sri. Manajemen Pembelajaran dalam Upaya Meningkatkan Mutu Pendidikan. Journal STIA ASMI, vol.4.

Gandhi, Teguh Wangsa. Mazhab-mazhab Filsafat Pendidikan. Jogjakarta: Ar-ruzz Media, 2014.

Hasanuddin. Tesis. Implementasi Manajemen Pembelajaran Pendidikan Agama Islam di SMP Negeri 3 Percut Sei Tuan", Prodi PAI, Konsentrasi Manajemen Pendidikan Islam, IAIN Sumatera Utara, 2014.

Ismail, Wahyuni .Analisis Komparatif Perbedaan tingkat religiusitas siswa di lembaga pendidikan pesantren, MAN, dan SMUN, Jurnal Lentera Pendidikan. vol.12, no.1, 2009.

Kompri. Manajemen Sekolah Teori dan Praktek. Bandung: Alfabeta, 2014.

Munirah, "Sistem Pendidikan di Indonesia Antara Keinginan dan Realita", Journal Auladuna, vol.2 no. 2, (2015), 234.

Nata, Abudin. Sosiologi Pendidikan Islam. Jakarta: PT. Rajawali Pres, 2014.

Purnama, Dian. Cermat Memilih Sekolah Menengah yang Tepat. Jakarta: Gagas Media, 2010.

Rachman, Budhy Munawar. Argumen Islam untuk Pluraisme, (Jakarta:Grasindo, 2010), 160

Roqib,Moh. Ilmu Pendidikan IslAM, Pengembangan Pendidikan Integratif di Sekolah, Keluarga dan Masyarakat. Yogyakarta: LKIS, 2009.

Satinem. Apresiasi Prosa Fiksi: Teori, Metode, dan Penerapan. Yogyakata:CV. Budi Utama, 2019.

Suheri, Eko. Pemanfaatan Lagu-Lagu Anak dalam Pembelajaran Tematik di TK IPAC Chandra Kusuma School. Medan:Sinar Jaya Press, 2010.

Syafaruddin dan Irwan Nasution. Manajemen Pembelajaran. Jakarta: Quantum Teaching, 2015. 
Teuku Mahmuddin, Tesis"Manajemen Pembelajaran PAI dalam Membentuk Karakter Siswa pada SMAN 1 Sigli Kabupaten Pidie", Program Studi Magister Administrasi Pendidikan, Universitas SyiahKuala, 2015.

Wiwi Hilwiah pengertian manajemen pembelajaran diakses pada 27 Oktober 2019 di https $/ /$ www.academia.edu/10500962/Manajemenpembelajaran

Zaenab dan M.Farid. Hubungan Antara Religiusitas dan Dukungan Sosial dengan Kebahagiaan Pelaku Konversi Agama. Jurnal Psikologi Indonesia, vol.4, No.01, 103. 